\title{
TINJAUAN YURIDIS TERHADAP TINDAK PIDANA DAYA PAKSA DAN PEMBELAAN TERPAKSA
}

\author{
Gowinda Prasad, Anak Agung Sagung Laksmi Dewi, I Made Minggu Widyantara \\ Fakultas Hukum, Universitas Warmadewa, Denpasar-Bali, Indonesia \\ gbanggo@gmail.com, laksmiidewi29@gmail.com, mademinggu21@gmail.com
}

\begin{abstract}
Abstrak
Daya paksa dan pembelaan terpaksa merupakan suatu tindak pidana yang dilakukan dengan melawan hukum, yang sebenarnya paksaan dari orang luar dan diluar kehendaknya serta ingin mempertahankan dirinya ataupun adanya ancaman dari orang luar yang tentunya perlu ditinjau juga mengenai alasan-alasan hingga doktrin dari daya paksa dan pembela paksa tersebut. Tujuan penelitian ini untuk mengungkap pengaturan tindak pidana daya paksa dan pembelaan terpaksa serta perlindungan hukum terhadap perbuatan tindak pidana daya paksa dan pembelaan terpaksa. Penelitian ini merupakan penelitian hukum normatif dengan pendekatan perundangundangan dan konseptual. Teknik pengumpulan data dilakukan melalui library research. Sumber bahan hukum yang digunakan yaitu sumber hukum primer dan sekunder. Setelah data dikumpulkan, selanjutnya data dianalisis dengan metode informal. Hasil penelitian mengungkapkan bahwa perlindungan hukum yang diberikan tentunya perlindungan jaminan keamanan fisik, harta dan nyawanya dan pemberian rehabilitasi psikologi dan sosialnya sebab dikarenakan adanya suatu tekanan.
\end{abstract}

Kata Kunci: Daya Paksa, KUHP, Perlindungan Hukum

\begin{abstract}
Forced power and forced defense are criminal acts committed against the law, which are actually coercion from outsiders and against their will and want to defend themselves or there are threats from outsiders which of course need to be reviewed also regarding the reasons to the doctrine of coercion and defense. force it. The purpose of this research is to reveal the regulation of criminal acts of coercion and forced defense as well as legal protection against acts of coercion and forced defense. This research is a normative legal research with a statutory and conceptual approach. Data collection techniques are carried out through library research. Sources of legal materials used are primary and secondary sources of law. After the data is collected, then the data is analyzed using informal methods. The results of the research reveal that the legal protection provided is of course the protection of physical, property and life security guarantees and the provision of psychological and social rehabilitation because there is a pressure.
\end{abstract}

Keywords: Force, Criminal Code, Protection

\section{PENDAHULUAN}

Kejahatan hanya dapat dicegah dan dikurangi tetapi sulit diberantas. Tindak pidana adalah perlakuan yang dilarang oleh aturan, perlakuan yang dilarang tersebut tentunya disertai sanksi. Pandangan ahli mengemukakan pidana yakni semua peraturan yang mengatur perbuatan yang melanggar dan dapat dipidana (Zaidan, 2015). Sehingga dapat disimpulkan unsur dari hukum pidana itu sendiri ada 2 yakni aturan hukum yang mengatur dan diancam dengan pidana apa dan peraturan mengenai pidana dan sanksi apa yang didapatkanya beserta pelaksanaanya.

Dalam menjatuhan pidana seorang yang melakukan tindak pidana bukan hanya saja melakunya namun tentunya pasti ada motifnya. Sebab, harus ada tanggungjawab dan kesalahan atas perbuatanya. Perlunya mempertimbangkan kesengajaan terdakwa dalam menentukan pertanggungjawaban pidananya. Sekalipun bisa dikatakan dalam rumusan tindak pidana yang didakwakan, tidak terdapat unsur "dengan Sengaja", tetapi hal ini harus dipertimbangkan oleh majelis hakim (Chairul, 2006).

Namun jika dipandang tetap saja orang tersebut telah melakukan suatu tindak pidana yang meskipun sifat melawan hukumnya yang sebenarnya ingin mempertahankan dirinya ataupun adanya ancaman dari orang luar yang diberikan. Namun, berbanding kebalik sehingga menuruti ancaman orang dari luar yang mengancam keselamatan dirinya dan ada juga yang harus mempertahankan 
dirinya secara terpaksa demi keselamatan nyawanya yang diakibatkan dari guncangan jiwanya yang sangat hebat sehingga membuat tindakan-tindakan yang sangat berlebihan. Meskipun disini bisa dikatakan unsur tersebut masuk kedalam tindak pidana daya paksa dan pembelaan terpaksa yang tidak dapat dihukum dikarenakan adanya unsur ketidaksengajaan untuk mempertahankan dirinya dari tekanan batin dan berbagai ancaman, disini perlu ditinjau juga mengenai alasan-alasan hingga doktrin dari daya paksa dan pembela paksa tersebut dan bagaimana tanggungjawab dari pelaku tindak pidana daya paksa dan pembela terpaksa itu sendiri beserta perlindungan hukum yang diberikan terhadap tindak pidana ini.

Sejumlah kajian telah dialamatkan pada pembahasan mengenai pembelaan terpaksa. Menurut (Widnyani et al (2020) konsep yang tertuang dalam Pasal 49 Ayat 1 yang diinterpretasikan sebagai noodweer bertujuan untuk melindungi diri sendiri maupun orang lain, kehormatan kesusilaan atau harta benda sendiri maupun orang lain, dimana jika dibandingkan dengan kasus begal yang dijadikan acuan telah jelas dianggap sebagai noodweer. Selain itu, dasar penghapusan pidana terhadap noodweer adalah kesimpulan hukum atas fakta yang terungkap di persidangan serta nilai-nilai yang mengikuti dan memahami rasa keadilan yang hidup dalam masyarakat sesuai sudut pandang hakim. Pasal 49 ayat (1) KUHP sebagai suatu alasan penghapus pidana merupakan pembelaan menghadapi serangan melawan hukum terhadap diri, kehormatan kesusilaan, atau harta benda sendiri maupun orang lain; dengan tidak memasukkan kehormatan dalam arti nama baik dan ketenteraman rumah (huisvrede) ke dalam kepentingan yang dapat dibela dengan pembelaan terpaksa (Lakoy, 2020). Lebih lanjut, noodweer masih tetap dipertahankan hingga sekarang sebagai salah satu alasan peniadaan pidana, sebagaimana dijabarkan di dalam pasal 49 ayat (1) KUHP (Marselino, 2020).

Maka berdasarkan uraian diatas, maka tujuan penelitian ini untuk mengungkap pengaturan tindak pidana daya paksa dan pembelaan terpaksa serta perlindungan hukum terhadap perbuatan tindak pidana daya paksa dan pembelaan terpaksa.

\section{METODE PENELITIAN}

Penelitian ini merupakan penelitian hukum normatif dengan menggunakan pendekatan pendekatan perundang-undangan dan pendekatan konseptual. Teknik pengumpulan data dilakukan melalui library research dengan cara menggunakan konsep-konsep para ahli ilmu hukum yang masih ada kaitanya dengan penegakan hukum daya paksa dan pembelaan terpaksa dan pandangan ahli hukum tentang tinjauan yuridis bagi tindak pidana daya paksa dan pembelaan terpaksa. Sumber bahan hukum yang digunakan berupa sumber bahan hukum primer dan sekunder dari literatur-literatur, berupa jurnal maupun buku yang terkait dengan pembelaan diri dan pembelaan terpaksa di dalam hukum pidana Indonesia. Setelah data dikumpulkan, maka disajikan dengan metode informal berupa deskripsi.

\section{HASIL DAN PEMBAHASAN}

\section{Pengaturan Tindak Pidana Daya Paksa dan Pembelaan Terpaksa}

Daya paksa tidak dijelaskan mengenai pengertianya didalam KUHP, namun didalam KUHP, hanya mengatur dan memberikan pengaturan tentang daya paksa. Menurut PAF Lamintang dalam buku Dasar-Dasar Hukum Pidana Indonesia, menulis menurut Memorie van Toelichting, daya paksa sebagai suatu penyebab yang datang dari luar yang membuat suatu perbuatan itu menjadi tidak dapat dipertanggungjawabkan kepada pelakunya atau setiap kekuatan, setiap paksaan, setiap tekanan dimana terhadap kekuatan, paksaan atau tekanan tersebut orang tidak dapat memberikan suatu perlawanan terhadap pelaku (Endro, 2016).

Untuk mengetahui batasan ruang lingkup berlakunya daya paksa, R. Sugandhi, S.H. dalam bukunya yang berjudul Kitab Undang-Undang Hukum Pidana mengatakan bahwa kalimat "karena pengaruh daya paksa" harus diartikan, Mengenai kekuasaan ini dapat dibedakan dalam 3 (tiga) macam antara lain sebagai berikut :

1. Bersifat Mutlak;

2. Bersifat Relatif;

3. Bersifat Suatu Keadaan Darurat.

Tindak pidana daya paksa diatur didalam KUHP dan tercantum didalam pasal 48 yang berbunyi sebagai berikut :

"Barang siapa yang melakukan perbuatan karena pengaruh daya paksa, tidak dipidana". 
Jadi, meskipun didalam KUHP tidak dijelaskan mengenai pengertian dari daya paksa itu sendiri, namun jika dikaitkan dengan pendapat para ahli, daya paksa itu sendiri dapat diartikan sebagai orang yang melakukan tindak pidana namun bukan atas kemauanya sendiri melainkan adanya paksaan dari orang lain sehingga mengakibatkan seorang melakukan suatu perbuatan pidana.

Pembelaan Terpaksa (noodweer) didalam KUHP dapat dibedakan menjadi 2 (dua), yaitu noodweer (pembelaan terpaksa) dan noodweer-exces (pembelaan darurat yang melampaui batas) terdapat dan dijelaskan didalam Pasal 49 KUHP yang berbunyi :

Pasal 49 ayat 1

"Tidak dipidana, barang siapa melakukan perbuatan pembelaan terpaksa untuk diri sendiri maupun untuk orang lain, kehormatan kesusilaan atau harta Benda sendiri maupun orang lain, karena ada serangan atau ancaman serangan yang sangat dekat pada saat itu yang melawan hukum."

Pasal 49 ayat 2

"Pembelaan terpaksa yang melampaui batas, yang langsung disebabkan oleh keguncangan jiwa yang hebat karena serangan atau ancaman serangan itu, tidak dipidana."

Menurut PAF Lumintang yang dijelaskan didalam buku Memorie van Toelichting, menjelaskan bahwa suatu tindak pidana pembelaan terpaksa tentunya harus memenuhi persyaratan antara lain sebagai berikut :

1. Terpaksa melakukan Pembelaan;

2. Kepentingan yang harus diserang;

3. Serangan harus melawan hukum.

Untuk mengetahui batasan ruang lingkup berlakunya pembelaan terpaksa, maka dapat berpedoman pada unsur-unsur pembelaan terpaksa dan pembelaan terpaksa melampaui batas menurut Andi Hamzah, dan syarat-syarat suatu tindakan dikategorikan sebagai noodweer menurut $\mathrm{R}$. Sugandhi, S.H. menurut Andi hamzah pada unsur-unsur pembelaan terpaksa dan pembelaan terpaksa melampaui batas dapat dijelaskan sebagai berikut (Hamzah, 1994):

1. Pembelaan bersifat terpaksa;

2. Yang dibela ialah diri sendiri, orang lain, kehormatan kesusilaan, atau harta benda sendiri atau orang lain;

3. Ada serangan sekejap atau ancaman serangan yang sangat dekat pada saat itu;

4. Serangan itu melawan hukum.

Menjelaskan bahwa pembelaan harus seimbang dengan serangan atau ancaman. Serangan tidak boleh melampaui batas keperluan dan keharusan. Asas ini disebut sebagai asas subsidiaritas (subsidiariteit). Harus seimbang antara kepentingan yang dibela dan cara yang dipakai di satu pihak dan kepentingan yang dikorbankan.

Bab I dan Bab II KUHP memuat : "Alasan-alasan yang menghapuskan, mengurangkan dan memberatkan pidana". Pembicaraan selanjutnya akan mengenai alasan penghapus pidana, ialah alasan-alasan yang memungkinkan orang yang melakukan perbuatan yang memenuhi rumusan delik, tidak dapat dipidana. Namun, Ilmu pengetahuan hukum pidana juga mengadakan pembedaan lain, sejalan dengan pembedaan antara dapat dipidananya perbuatan dan dapat dipidananya pembuat. Penghapusan pidana dapat menyangkut perbuatan atau pembuatnya, maka dibedakan dua jenis alasan penghapus pidana :

1. Alasan pembenar (rechtvaardigingsgrond, fait justificatif, rechtfertigungsgrund).

2. Alasan pemaaf atau alasan penghapus kesalahan (schulduitsluittingsgrond-fait d'excuse, entschuldigungsdrund, schuldausschliesungsgrund).

Van Hamel menyatakan bahwa tekanan daya paksa itu dapat bersifat absolut dan dapat pula bersifat relatif. Daya paksa merupakan alasan pembenar sebab jika dalam hal hukum masih tetap dipertahankan, maka disitu ternyata bahwa tata hukum atau menghendaki supaya orang mempunyai keberanian yang luar biasa.

Menurut Budayawan (2018) bahwa harus dipisahkan antara daya paksa sempit dan keadaan darurat. Dalam hal yang pertama, disitu tidak ada kesalahan (alasan pemaaf) sedangkan dalam hal yang kedua yang hapus ialah sifat melawan hukum perbuatan (alasan pembenar). Pertanggungjawaban pidana mempunyai nilai-nilai kepastian yang berpijak kepada norma-norma pembentuk undang-undang dan nilai-nilai keadilan pada undang-undang dalam penentuan pertanggungjawaban pidana pada pembuat. Suatu penilaian akan menjadi berbeda apabila seluruh 
unsur tindak pidana telah terpenuhi dan tindak pidana yang dilakukan oleh pembuat. Kedua dasar yaitu dapat dibenarkan perbuatan dan dimaafkanya pembuat merupakan dasar peniadaan pertanggungjawaban pidana, yaitu sebagai alasan pembenar ini berakibat tidak dipertanggungjawabkannya pembuat atas tindak pidana yang dilakukannya. Tidak adanya pertanggungjawaban pidana menjadi pembuat tidak dapatnya dipidana, oleh karena itu adanya alasan pemaaf dan alasan pembenar yang telah disebutkan diatas, maka dapat juga digolongkan dan termasuk kedalam unsur-unsur dari pertanggungjawaban pidana. Sesuai dengan asas tiada pidana tanpa adanya kesalahan, maka pertanggungjawaban pidana juga bersifat psychologis. Alasan pemaaf yang merupakan keadaan psychis pembuat ini menghilangkan atau menghapuskan kesalahan yang bersifat psychologis. Alasan pemaaf merupakan peniadaan pertanggungjawaban pidana yang berhubungan erat dengan keadaan psychis pembuat. Alasan pemaaf didalam English Common Law digunakan untuk pembelaan (defence) dengan berbagai macam-macam keadaan psychis pembuat.

Jadi dapat disimpulkan seorang yang terkena daya paksa perbuatanya dapat dimaafkan sebab perbuatanya dilakukan diluar dari kehendaknya, sedangkan perbuatan pembelaan terpaksa, perbuatanya dibenarkan, dikarenakan memang benar orang tersebut melakukan tindak pidana dengan melakukan perlawanan hingga menimbulkan suatu yang tak terduga kepada yang mengancamnya, namun perbuatanya juga dapat dimaafkan, sebab orang yang melakukan pembelaan terpaksa, membela nyawanya dari suatu ancaman yang datang kepadanya hingga mengakibatkan pelaku yang mengalami ancaman yang mengancam jiwanya atau sampai merenggut jiwanya akibat reflek dari korban yang diancamnya balik menyerangnya. Namun perbuatan pembelaan paksa yang melampaui batas juga dapat dimaafkan. Sebab, suatu tindakanya memang berasal dari guncangan jiwanya yang merespon sangat berlebihan akibat rasa ketakutanya sampai mengancam nyawa pelaku juga dapat dimaafkan. Sebab perbuatan tersebut memang dibenarkan akibat ulah pembela terpaksa namun perbuatanya juga dapat dimaafkan atau tidak dapat dipertanggungjawabkan sebab jiwa dan psikisnya diluar kendalinya.

\section{Perlindungan Hukum terhadap Perbuatan Tindak Pidana Daya Paksa dan Pembelaan Terpaksa}

Daya paksa adalah "setiap kekuatan, setiap dorongan, setiap paksaan yg tidak dapat dilawan. Seorang yang melakukan tindak pidana daya paksa dan pembelaan terpaksa tentunya harus diberikan perlindungan hukum, Perlindungan hukum adalah sebuah hak yang bisa didapatkan oleh semua warga negara secara merata dan hak itu diberikan oleh pemerintah bila warga negara tersebut sudah memenuhi syarat-syarat tertentu dan tentunya berdasarkan adanya kepastian hukum yang termuat didalam peraturan perundang-undangan.

Dapat diketahui bersama KUHAP lebih mengutamakan hak-hak tersangka/terdakwa, namun dapat demikian terdapat juga beberapa asas KUHAP yang dapat dijadikan landasan perlindungan korban, antara lain :

1. Perlakuan yang sama didepan hukum;

2. Asas cepat, sederhana dan biaya ringan;

3. Peradilan yang bebas;

4. Peradilan terbuka untuk umum;

5. Ganti kerugian;

6. Keadilan dan kepastian hukum.

Tentunya perlindungan bagi korban dan hak-hak yang diberikan terhadap korban telah diakomodasikan didalam KUHAP, tetapi mengingat jenis tindak pidana yang semakin beragam menimbulkan efek keselamatan bagi korban seperti halnya daya paksa yang menjadi korban bagi seorang yang memiliki kekuatan yang sangat besar dan memiliki kekuasaan atau wewenang yang bertindak menekan korban hingga melakukan perbuatan yang melanggar norma, tentunya korban tersebut mendapatkan tekanan psikis yang sangat besar. Lain halnya dengan korban perlindungan terpaksa juga yang mempertahankan dirinya dari sebuah ancaman yang mengancam keselamatan jiwa dan raganya tentunya perlu mendapatkan pembuktian dan keadilan hingga mampu menjelaskan mengapa orang tersebut dapat melakukan pembelaan yang berujung mengancam pelakunya. Hal ini tentunya sangat diperlukanya perlindungan bagi tindak pidana daya paksa dan pembelaan terpaksa untuk mendapatkan hak-hak mereka yang adil dan menjamin keselamatanya (Rocky Marbun, 2010) yang diatur didalam pasal 5 ayat (1) UU PSK menyebutkan : 
Pasal 5 ayat (1) huruf a

"Memperoleh perlindungan atas keamanan pribadi, keluarga, dan harta bendanya, serta bebas dari ancaman yang berkenaan dengan kesaksian yang akan, sedang atau telah diberikanya".

Pasal 5 ayat (1) huruf b

"Ikut serta dalam proses memilih dan menentukan bentuk perlindungan dan dukungan keamanan"

Apabila korban daya paksa mengalami perbuatan pelanggaran hak asasi manusia yang berat. Maka, selain hak yang telah dijelaskan diatas, korban juga berhak mendapatkan sesuai yang dijelaskan didalam pasal 6 antara lain:

a) Bantuan medis dan;

b) Bantuan rehabilitasi psiko-sosial.

Dapat dijelaskan bahwa seorang yang menjadi korban tidak dapat langsung menuntut haknya tanpa melalui proses hukum. Seorang korban berhak mendapatkan perlindungan atas keamanan pribadinya atas apa yang akan didapatkanya. Terlebih lagi korban yang terancam jiwanya sangat perlu untuk dilindungi terlebih lagi tujuan dari hukum itu sendiri antara lain memberikan keadilan bagi seluruh masyarakat Indonesia dan memberikan rasa adanya kepastian hukum yang diberlakukanya dan memberikan adanya manfaat dari aturan yang berlaku didalam Negara Kesatuan Republik Indonesia.

\section{SIMPULAN DAN SARAN}

\section{Simpulan}

Pengaturan jenis-jenis alasan pemaaf tindak pidana daya paksa dan pembelaan terpaksa dibagi menjadi dua antara lain, Alasan pembenar menghapuskan sifat melawan hukumnya perbuatan, meskipun perbuatan ini telah memenuhi rumusan delik dalam undang-undang. Kalau perbuatannya tidak melawan hukum maka tidak mungkin ada pemidanaan. Alasan pembenar yang terdapat dalam KUHP ialah pasal 48 (daya paksa), pasal 49 ayat (1) (pembelaan terpaksa) pasal 49 ayat (2) (pembelaan terpaksa yang melampaui batas). Alasan pemaaf menyangkut pribadi si pembuat, dalam arti bahwa orang ini tidak dapat dicela (menurut hukum) dan tidak dapat dipertanggungjawabkan, meskipun perbuatannya bersifat melawan hukum. Perlindungan hukum yang diberikan terhadap tindak pidana daya paksa dan pembelaan terpaksa Tentunya didalam keadaan darurat hukum sangat menjunjung kepentingan hukum yang lebih tinggi yang ditentukan secara konkrit dengan mempertimbangkan keadaan-keadaan yang menyertai perbuatan, dalam konteks tersebut diberikan otonomi sebagai pengemban hak dan kewajibanya untuk menentukan pilihan hukumnya. Adapun perlindungan hukum sebagai korban diatur didalam pasal 3 dan pasal 5 dan pasal 6 UU PSK yang mengalami perbuatan pelanggaran HAM berat akan mendapatkan bantuan medis dan bantuan rehabilitasi psiko-sosial.

\section{Saran}

Kepada masyarakat khususnya korban daya paksa dan pembela terpaksa agar dapat mengetahui didalam keadaan darurat hukum sangat menjunjung kepentingan hukum yang lebih tinggi yang ditentukan secara konkrit dengan mempertimbangkan keadaan-keadaan yang menyertai perbuatan. Kepada pemerintah dalam hal ini sebagai pemegang regulasi, wajib untuk lebih meningkatkan pengawasan dan memberikan kepastian hukum mengenai perlindungan bagi masyarakat agar terhindar dari tindak pidana yang sewaktu-waktu dapat mengancam nyawa, harta, maupun fisiknya.

\section{DAFTAR PUSTAKA}

Budayawan, T. (2018). Pertanggungjawaban Pidana Menurut Hukum Pidana Tentang Daya Paksa (Overmacht). E-Jurnal: Spirit Pro Patria, 4(2), 115-124.

Chairul, H. (2006). Dari Tiada Pidana Tanpa Kesalahan Menuju Kepada Tiada Pertanggungjawaban Pidana Tanpa Kesalahan (Tinjauan Kritis terhadap Teori Pemisahan Tindak Pidana dan Pertanggungjawaban Pidana. Kencana, Jakarta.

Endro, P. D. (2016). Hukum Pidana. Airlangga University Pers, Surabaya.

Hamzah, A. (1994). Asas-Asas Hukum Pidana. PT Rineka Cipta, Jakarta. 
Lakoy, R. E. K. (2020). Syarat Proporsionalitas dan Subsidaritas dalam Pembelaan Terpaksa Menurut Pasal 49 Ayat (1) Kitab Undang-undang Hukum Pidana. Jurnal Lex Crimen, 9(2), 45-52.

Marselino, R. (2020). Pembelaan Terpaksa yang Melampaui Batas (Noodweer Exces) Pada Pasal 49 Ayat (2). Jurnal Jurist-Diction, 3(2), 633-647.

Rocky, M. (2010). Cerdik dan Taktis menghadapi Kasus Hukum. Visimedia, Jakarta.

Widnyani, I. A. M., Dewi, A. A. S. L., \& Karma, N. M. S. (2020). Tinjauan Yuridis terhadap Pembelaan Terpaksa (Noodweer) sebagai Alasan Penghapus Pidana. Jurnal Preferensi Hukum, $1(1), 195-200$.

Zaidan, M. A. (2015). Menuju Pembaruan Hukum Pidana. Sinar Grafika, Jakarta. 